\title{
How Russian became Typologically Unusual: the History of Russian Temporal Adverbials with $v$ 'in(to)"
}

\author{
Tore Nesset, University of Tromsø
}

\begin{abstract}
The present study explores the relationship between historical linguistics and language typology in Russian temporal adverbials. It is argued that temporal adverbials with $v$ 'in(to)' are typologically unusual, and that this is the result of historical processes targeting case, aspect, and the lexicon. In section 1, I clarify Talmy's (2000) generalization that closed-class elements tend to have magnitudeneutral ("topological") rather than magnitude-sensitive ("Euclidean") meanings. Section 2 demonstrates that Russian temporal adverbials offer an exception from Talmy's generalization, while in section 3 it is argued that there are no traces of magnitude-sensitive temporal adverbials in Old Russian. In section 4, I show how magnitude sensitivity arose in late Middle Russian as a result of the interaction of (a) case syntax (the replacement of bare cases by analytical constructions with prepositions), (b) aspect (the emergence of atelic perfective verbs), and (c) lexicon (the meaning of nedelja). The present study lends support to Harris' $(2008,76)$ idea that typologically unusual constructions may develop as a result of the "unusual cooccurrence of quite usual processes".
\end{abstract}

\section{Topological vs. Euclidean Semantics}

In his typological work on cognitive semantics, Talmy $(2000,25$, see also Talmy 1977 and Turner 2002) claims that the meaning of closed-class elements "generally have a topological rather than a Euclidean character". The terms "topological" and "Euclidean" may be opaque, but for present purposes it is sufficiently precise to restate Talmy's generalization as follows: "the meaning of closed-class elements generally have magnitude-neutral rather than magnitude-sensitive meanings." Closed-class elements include adpositions and grammatical morphemes, such as tense and case suffixes.

In order to assess the entailments of Talmy's generalization, let us consider two of his examples. The first concerns the English preposition across (Talmy 2000, 26):

(1) a. The ant crawled across my palm.

\footnotetext{
*I would like to express my gratitude to the Centre for Advanced Study at the Norwegian Academy of Science and Letters, since the work on this article began while I was a fellow there in 2011-2012. Thanks are also due to the members of the CLEAR (Cognitive Linguistics: Empirical Approaches to Russian) research group at the University of Tromsø for discussion of an earlier version of this article. Finally, I would like to thank the editor of Scando-Slavica and an anonymous referee for valuable comments, which led to a number of improvements to the article.
} 
b. The bus drove across the country.

Whereas sentence (1a) describes an ant's traversal along a very short path, the bus in (1b) covers a large distance. However, across is equally felicitous in both examples; the meaning of the preposition is magnitude-neutral (topological) since the magnitude of the distance covered by the subject is irrelevant for the use of the preposition.

Talmy's generalization also holds for grammatical morphemes such as the past tense marker -ed in English. Consider Talmy's $(2000,26)$ second example:

(2) Alexander died, with dignity.

As pointed out by Talmy $(2000,26)$, the use of -ed in (2) is equally felicitous "whether the time referred to was last year, in speaking of an acquaintance, or over two millennia ago, in speaking of Alexander the Great." The meaning of the past tense morpheme is magnitude neutral - it is not sensitive to the distance in time between Alexander's death and the time of speaking.

Are there exceptions to Talmy's generalization? Although Talmy (2000) does not rule out this possibility, he does not discuss any counterexamples. However, in the following section I will explore one exception from Contemporary Standard Russian.

\section{A Modern Russian Exception}

In Contemporary Standard Russian, temporal adverbials with the preposition $v$ 'in(to)' specify when an event takes place: ${ }^{1}$

a. Èto slučilos' v noč' ${ }_{\text {Acc }} \mathrm{s}$ dvadcat' sed'mogo janvarja na dvadcat' vos'moe. (Koneckij 1979)

'This happened in the night between January 27 and 28.'

b. Èto slučilos' v 1969 godu 1 Loc. (Nauka i žizn' 2009)

'This happened in 1969.'

In (3a) $v$ governs the accusative, whereas in (3b) the locative is used. The distribution of the cases is not random. As demonstrated in Nesset 2004 (see also Makarova and Nesset to appear), the accusative tends to be used for time spans shorter than a week, while longer time spans generally occur in the locative. Thus, the accusative phrase $v$ noč 'Acc in (3a) can be replaced by phrases with time spans such as second ( $v$ ètu sekundu $u_{\mathrm{Acc}}$ 'in that second'), minute ( $v$ ètu minutu $u_{\mathrm{Acc}}$ 'in that

\footnotetext{
1 While this study focuses on $v$, other prepositions also occur in temporal adverbials, notably $n a$ 'on' as in na prošloj nedele LOC 'last week'. We will return to this construction in section 4.3 below.

All numbered examples from Contemporary Standard Russian cited in the present study are culled from the Russian National Corpus (www.ruscorpora.ru). For examples from fiction, I give the name of the author and the year of publication in parentheses. For examples from non-fiction, in addition to the year of publication I give the name of the journal/newspaper in italics. For the convenience of the reader, the relevant temporal adverbials in each sentence are boldfaced, and the case is indicated in subscript.
} 
minute), day parts ( $v$ tot večer ${ }_{\mathrm{Acc}}$ 'on that evening'), and days of the week ( $v$ sreduAcc 'on Wednesday') - all of which involve the accusative case. Longer time spans such

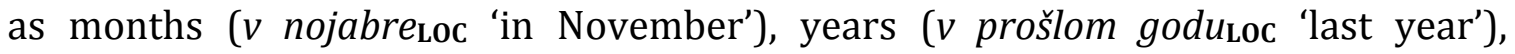
decades ( $v$ sledujuščem desjatiletii $L_{\text {Loc }}$ 'in the following decade'), and centuries ( $v$ dvadcatom veke Loc 'in the $20^{\text {th }}$ century') occur in the locative.

Parallel examples such as (3a) and (3b) suggest that we are dealing with an opposition between equals (what Trubetzkoy $(1939,67)$ would term an "equipollent opposition"). However, it may be more accurate to analyze the relationship between the two cases as a so-called privative opposition, where the accusative represents the unmarked, default case that occurs whenever the specifications for the use of the locative are not met. As evidence, consider examples with unbounded time spans that do not have any definite length, such as naše vremja 'our time':

(4) Mnogoe li izmenilos' v naše vremja

'Has much changed in our time?'

Since unbounded time spans combine with the accusative, the simplest way to account for the distribution of the locative and accusative cases is to say that the locative is used for bounded time spans longer than a week, while the accusative is used elsewhere.

Two further arguments support the idea that the accusative is the unmarked, default case in temporal adverbials with $v$ 'in(to)'. First, if time spans longer than a week occur in the plural, the accusative is used instead of the locative: ${ }^{2}$

(5) V èti gody 1999)

'During these years he first gained serious attention.'

Arguably, pluralization removes the boundaries of the relevant time span, since èti gody 'these years' do not have a clearly defined length. In this way, examples like (5) resemble examples like (4) (cf. Nesset 2004, 302ff.). A second argument comes from constructions with modifiers in the genitive. If time spans longer than a week combine with modifiers in the genitive, the time span occurs in the accusative instead of the locative (cf. Vsevolodova 1975, 116): ${ }^{3}$

(6) Ja rodilsja $\mathbf{v}$ god $_{\text {ACC }}$ smerti $_{\text {GEN }}$ Lenina. (Vasil'ev 2003)

'I was born the year Lenin died.'

\footnotetext{
${ }^{2}$ An interesting exception from the generalization that pluralization yields the accusative is the decade construction, where both the accusative and the locative are attested: $v$ dvadcatye gody ACC $_{\text {vs. }}$ $v$ dvadcatyx godax $_{\mathrm{LOC}}$ 'in the twenties'. The decade construction is discussed in detail in Nesset 2004, 304-308.

${ }^{3}$ A similar effect is observed for clausal and some adjectival modifiers. For discussion, the interested reader is referred to Nesset 2004, 311.
} 
Examples such as (5) and (6) indicate that in temporal adverbials of the relevant type the accusative has a wider distribution than the locative, and it is therefore natural to regard the accusative as the default case.

As shown by Makarova and Nesset (to appear), the $v+$ accusative/locative constructions compete with a number of other types of temporal adverbials. For the purposes of the present study, it is sufficient to consider two competing constructions. First, the bare instrumental is used for day parts and seasons:
a. Èto slučilos' rannim utrom INST. (Rytchèu 1970-1977)
'This happened early in the morning.'
b. Èto slučilos' prošlym letom ${ }_{\text {INST }} \mathrm{v}$ derevne. (Bunin 1916)
'This happened last summer in the countryside.'

Since day parts and seasons refer to the diurnal and annual cycles of the sun, I will refer to them as "cyclic time spans". Second, dates occur in the bare genitive:

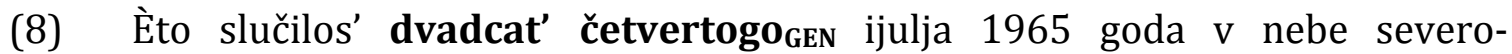
vostočnee Chanoja. (Vozdušno-kosmičeskaja oborona 2003)

'This happened on the 24th of July 1965 in the sky north-east of Hanoi.'

Notice that for dates the $v+$ accusative/locative constructions are not used, whereas for cyclic time spans both the bare instrumental and $v+$ accusative are attested. However, I will not discuss the factors that favor either construction, since the following simple rules are sufficient to address the main point of this section, namely the fact that they represent an exception to Talmy's generalization about magnitude-neutral (topological) semantics for closed-class elements: ${ }^{4}$
a. Unmodified bounded time spans longer than a week in the singular $\rightarrow v+$ locative
b. Cyclic time spans (day parts and seasons) $\rightarrow$ bare instrumental or $v+$ accusative
c. Dates $\rightarrow$ bare genitive
d. Elsewhere $\rightarrow v+$ accusative

In (9a), the epithet "unmodified" accommodates the fact that the locative is not used in combination with genitive modifiers (see (6)). The epithet "bounded" is included to rule out the locative in examples such as (4), and the singular is mentioned since as shown in (5) the locative is not used for time spans in the plural. However, the most interesting part of rule (9a) is the phrase "longer than a week". Since this shows that the rule is sensitive to the length of the time span in question, (9a) is magnitude-sensitive and therefore represents an exception to Talmy's generalization discussed in the previous section. Magnitude-sensitive rules like (9a)

\footnotetext{
${ }^{4}$ Notice that the arrows in (9) do not represent rewrite rules of the type used in classical generative linguistics (e.g. Chomsky and Halle 1968). For the purposes of the present study, arrows symbolize a dependency relationship between contexts and the constructions occurring in those contexts.
} 
appear to be typologically unusual, so the question arises as to how this rule developed historically. This question will occupy us in the remainder of this article.

\section{Old Russian: The Hypatian Chronicle}

In order to shed light on the historical development that created the magnitudesensitive rule, in this section I show that there was no such rule in Old Russian, and that the $v b$ + locative construction was marginal in Old Russian temporal adverbials. Since the magnitude-sensitive rule in (9a) that we are interested in concerns time spans longer than a week, I will consider only such time spans in the following. More precisely, I will explore temporal adverbials with 'year' and 'month', which are frequent enough to permit quantitative analysis. My data come from the Hypatian Chronicle, which is available electronically as part of the Regensburg Russian Diachronic Corpus. ${ }^{5}$ Needless to say, the Hypatian Chronicle (or chronicles in general) is not representative of all literary genres in Old Russian, but the data presented below suffice to show that the distribution of cases in temporal adverbials has changed between Old Russian and Contemporary Standard Russian.

\subsection{Year}

In order to investigate case usage in temporal adverbials with 'year', I extracted all examples with lěto from the corpus and identified 776 temporal adverbials with this word. ${ }^{6}$ These temporal adverbials occur in two different environments. First, each section of the chronicle starts with the formula vъ lèto followed by a numeral indicating the relevant year:

(10) V lěto $A$ Acc 6492. Ide Volodimirъ na radimiči. (p. 71) 'In 6492 (984) Vladimir went against the radimiči.'

I will refer to examples of this type as "new information", since the relevant year is mentioned for the first time. There are 421 examples of the new information type in my database, and all of them have lěto in the accusative.

The remaining examples can be labeled "given information", since they describe a year that has been mentioned previously. Typically, the examples of the given information type include the determiners $s b$ 'this' or $t z$ 'that' followed by the particle že 'same':

(11) V se že lěto ${ }_{\text {Acc }}$ rodisja Svjatoslavъ u Igorja. (p. 34)

'In the same year Svjatoslav was born to Igor'.'

\footnotetext{
5 The Regensburg Russian Diachronic Corpus, which can be accessed at http://rhssl1.uniregensburg.de/SlavKo/korpus, is based on Ipat'evskaja letopis' (1998). The number in parentheses after each example is the page number as provided in the Regensburg Russian Diachronic Corpus.

${ }^{6}$ Notice that lěto is polysemous and denotes both 'summer' and 'year'. The word godz is also attested in the Hypatian Chronicle, but only in the meaning 'time'. However, section 4.1 explores examples from Middle Russian where godz denotes 'year'.
} 
In (11), we have the $v ъ+$ accusative construction, but another frequent construction is the bare genitive:

(12) Togo že lětagen vygna Vseslavъ Svjatopolka is Polotbska. (p. 164) 'In the same year Vseslav chased Svjatopolk out of Polock.'

A third construction is the bare locative:

(13) Tom že lětěLoc javisja zvězda s chvostomъ na zapadě. (p. 257) 'In the same year a star with a tail appeared in the west.'

In addition, there are examples with the $v ъ+$ locative construction:

(14) V tom že lětěLoc rodisja u Jaroslava drugyj syn. (p. 136) 'In the same year Jaroslav had another son.'

Finally, the bare accusative is attested:

(15) Se že lěto ${ }_{A c c}$ privezoša iz Novagoroda Mbstislavu ženu druguju. (p. 286) 'In the same year they brought Mstislav a new wife from Novgorod.'

The distribution of the five constructions mentioned above is summarized in Table 1 and Figure 1. The numbers concern only the given information type. (Recall that for new information $v b+$ accusative is the only attested construction, so an overview in tabular form is superfluous.). Table 1 and Figure 1 show that three constructions are widely attested: $v b+$ accusative, the bare genitive, and the bare locative. Since $v z+$ accusative is the only construction that occurs both as new and given information, it is reasonable to regard this construction as the default in Old Russian, just like it is in Contemporary Standard Russian. However, apart from this similarity, the Old Russian system displays a number of differences from the modern system outlined in the previous section. First, the bare genitive has a much wider distribution in Old Russian than in Contemporary Standard Russian, where it is restricted to dates. Second, the bare locative, which is not attested in Contemporary Standard Russian at all, is widely used in Old Russian temporal adverbials. Third, the $v b+$ locative construction is marginal in Old Russian, but widely used in Contemporary Standard Russian for 'year'.7

\begin{tabular}{lrr} 
Construction & \# Examples & \% Examples \\
\hline$V ъ+$ accusative & 125 & 35 \\
$V ъ+$ locative & 13 & 4 \\
Bare accusative & 4 & 1 \\
Bare locative & 102 & 29 \\
Bare genitive & 111 & 31
\end{tabular}

\footnotetext{
${ }^{7}$ I will not comment on the bare accusative, which is tangential to the present study. A possible interpretation is to consider the few attestations of this constructions a variant of the $v b+$ accusative construction where the preposition has been omitted due to scribal error. However, this question is beyond the scope of the present study and must be left open for future research.
} 
Total

Table 1: Given information - distribution of constructions (raw numbers and percentages)

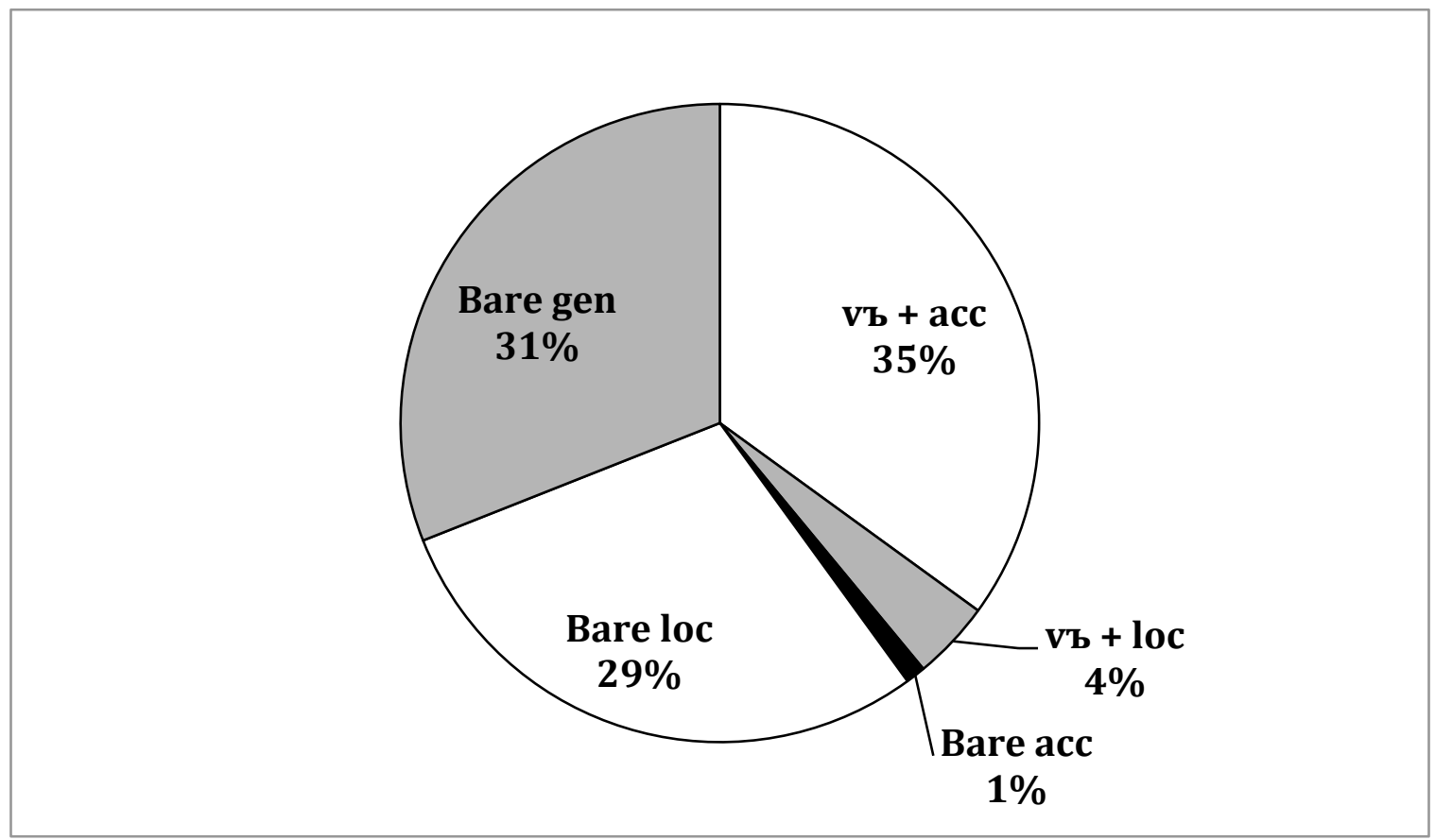

Figure 1: Given information - distribution of constructions (percent)

Although according to rule (9a) above 'year' takes the $v+$ locative construction in Contemporary Standard Russian, there is one environment where the bare genitive is required. When a shorter time span is mentioned in addition to the year, the year is in the genitive. Example (8), here repeated as (16), illustrates this:

(16) Èto slučilos' dvadcat' četvertogo ijulja $\mathbf{G E N}_{1965}$ goda $_{\text {GEN }} \mathrm{v}$ nebe severovostočnee Chanoja. (Vozdušno-kosmičeskaja oborona 2003)

'This happened on the 24th of July 1965 in the sky north-east of Hanoi.'

Examples of this kind involve part-whole relations; the date is part of the month, which in turn is part of the year. In such part-whole relations, the whole (the longer time span) occurs in the genitive. This is a general rule not only for temporal expressions, but also for other domains (e.g. pervyj vzvod vtoroj roty 'the first platoon of the second company'). Was there a similar part-whole rule for the genitive in Old Russian temporal adverbials? Examples of the following type suggest that this was not the case, since all three major constructions $(v z+$ accusative, the bare genitive and the bare locative) are attested in part-whole relations:

(17) V se lěto ${ }_{A c c}$ prestavisja Rostislavъ, synъ Mьistislavlb, vnukъ Izjaslavlja, měsjaca $_{\text {GEN }}$ oktjabrja $a_{\text {GEN }}$ Vъ 1. (p. 216)

'In the same year Rostislav, the son of Mstislav and the grandson of Izjaslav, died in the month of October on the first day.'

(18) Togo že lětagen pridoša pruzii, avgustagen Vъ 1 denb. (p. 255) 
'In the same year grasshoppers came in August on the first day.'

(19) Tomъ že lětě měsjaca nojabragen vъ 3 denb. (p. 273)

'In the same year Janka, the daughter of Vsevolod and the sister of Vladimir, died in the month of November on the third day.'

Notice that in these examples the year is topicalized (given information, placed first in the sentence), while the month and the day belong to the focus part of the sentences (new information, placed at the end). This is typical for the Hypatian Chronicle. The data in Table 2 show that part-whole relations are less frequently attested for the bare locative construction. The difference is statistically significant, but the effect size is small, which indicates that the presence or absence of a partwhole relation is not an important factor for predicting the choice of construction $(v ъ+$ accusative, bare locative, or bare genitive $){ }^{8}$

\begin{tabular}{lrrrrrr} 
& \multicolumn{2}{c}{$v ъ+$ accusative } & \multicolumn{2}{c}{ Bare locative } & \multicolumn{2}{c}{ Bare genitive } \\
& Raw \# & $\%$ & Raw \# & $\%$ & Raw \# & $\%$ \\
\hline Part-whole & 32 & 26 & 13 & 13 & 29 & 26 \\
Not Part-whole & 93 & 74 & 89 & 87 & 82 & 74 \\
Total & 125 & 100 & 102 & 100 & 111 & 100
\end{tabular}

Table 2: Distribution of part-whole relations for three major constructions (raw numbers and percent)

Since $v+$ locative is central in Contemporary Standard Russian it may be worthwhile taking a closer look at the thirteen attested examples with $v$ r + locative in Old Russian. Four of these examples are from the older part of the Hypatian Chronicle, which contains the Primary Chronicle (Povest' vremennych let). Table 3 compares the Hypatian version with four other sources (the Laurentian, Radziwiłł, Academy, and Chlebnikov copies) and four editions (Byčkov, Šachmatov, Lichačev and Ostrowski). As shown in the table, no examples have $v z+$ locative in all the relevant manuscripts, and only one example has consistently been reconstructed as $v z+$ locative in all the editions discussed in Ostrowski (2003). This indicates that the $v z+$ locative construction may have been even more marginal in Old Russian than the numbers in Table 1 suggest.

\begin{tabular}{lllll} 
& p. 136 & p. 250 & p. $256(\mathrm{a})$ & p. $256(\mathrm{~b})$ \\
& $(149,9)^{9}$ & $(275,7)$ & $(280,8)$ & $(280,11-12)$ \\
\hline Laurentian & Num + Gen & Bare locative & Bare locative & Bare genitive \\
Radziwiłł & $V \mathrm{~b}+$ locative & Bare locative & Bare genitive & omitted \\
Acadademy & $V \mathfrak{b}+$ locative & Bare locative & Bare genitive & omitted
\end{tabular}

\footnotetext{
8 Pearson's Chi-squared test $(\mathrm{X}$-squared $=7.1593, \mathrm{df}=2)$ yields $\mathrm{p}$-value $=0.03$, which indicates that the difference is just barely statistically significant. Cramer's V-value is 0.1 , which indicates a small effect size (King and Minium 2008, 327-329).

${ }^{9}$ The page numbers refer to the printed academy edition of the Hypatian chronicle (Ipat'evskaja letopis' 1998). Numbers in parentheses refer to the column and line numbering system used by Ostrowski (2003).
} 


\begin{tabular}{|c|c|c|c|c|}
\hline $\begin{array}{l}\text { Hypatian } \\
\text { Chlebnikov }\end{array}$ & $\begin{array}{l}V_{6}+\text { locative } \\
V_{z}+\text { locative }\end{array}$ & $\begin{array}{l}\text { Bare loc }\left(\text { sic!) }{ }^{10}\right. \\
\text { Bare locative }\end{array}$ & $\begin{array}{l}V ъ+\text { locative } \\
V ъ+\text { locative }\end{array}$ & $\begin{array}{l}V z+\text { locative } \\
V z+\text { locative }\end{array}$ \\
\hline Byčkov & $V_{6}+$ locative & Bare locative & Bare locative & Bare genitive \\
\hline Šachmatov & $V_{6}+$ locative & Bare locative & Bare locative & Bare genitive \\
\hline Lichačev & $V_{z}+$ locative & Bare locative & Bare locative & Bare genitive \\
\hline Ostrowski & $V_{6}+$ locative & Bare locative & Bare locative & $\begin{array}{l}\text { Bare genitive/ } \\
v ъ+\text { locative }\end{array}$ \\
\hline
\end{tabular}

Table 3: Comparison of the four v6 +locative examples in various versions of the Primary Chronicle (based on Ostrowski 2003)

Table 4 provides an overview of the attestations of the second part of the Hypatian Chronicle, which contains the so-called Galicko-Volynskoe povestvovanie. Ipat'evskaja letopis' 1998 provides data from three sources that are compared in the table: Chlebnikovskij spisok, Pogodinskij spisok, as well as the 1998 edition itself. The table shows that only three examples have $v 6+$ locative in all the sources, which once again suggests that the $v ъ+$ locative may have been even more marginal than the statistics in Table 1 indicate.

\begin{tabular}{|c|c|c|c|c|c|c|c|c|c|}
\hline & $\begin{array}{c}\text { p. } \\
359\end{array}$ & $\begin{array}{c}\text { p. } \\
562\end{array}$ & $\begin{array}{c}\text { p. } \\
564\end{array}$ & $\begin{array}{c}\text { p. } \\
580\end{array}$ & $\begin{array}{c}\text { p. } \\
604\end{array}$ & $\underset{613}{\text { p. }}$ & $\begin{array}{c}\text { p. } \\
630\end{array}$ & $\begin{array}{c}\text { p. } \\
776\end{array}$ & $\begin{array}{c}\text { p. } \\
861\end{array}$ \\
\hline 1998 edition & $v z+L$ & $v 6+L$ & $v 6+\mathrm{L}$ & $v 6+L$ & $v 6+\mathrm{L}$ & $v 6+L$ & $v z+L$ & $v 6+\mathrm{L}$ & $v z+L$ \\
\hline Chlebnikovskij & $v z+L$ & $v ъ+A$ & $\begin{array}{c}\text { bare } \\
\text { G }\end{array}$ & $v ъ+A$ & $v z+\mathrm{A}$ & $\begin{array}{c}\text { bare } \\
\text { G }\end{array}$ & $v z+A$ & $v z+L$ & $v z+L$ \\
\hline Pogodinskij & $v ъ+L$ & $v ъ+L$ & $\begin{array}{c}\text { bare } \\
\text { G }\end{array}$ & $\begin{array}{c}\text { bare } \\
\text { G }\end{array}$ & $v ъ+A$ & $\begin{array}{c}\text { bare } \\
\text { G }\end{array}$ & $v z+A$ & $v ъ+L$ & $v z+L$ \\
\hline
\end{tabular}

Table 4: Comparison of the $v$ +locative examples in three versions of the second part of the Hypatian Chronicle (Data and page numbers from Ipat'evskaja letopis' 1998)

The question now arises as to how the $v z+$ locative construction developed from being marginal in Old Russian to becoming the main construction for 'year' in Contemporary Standard Russian. We turn to this question in section 4, but first we consider 'month' in Old Russian in section 3.2, which provides additional evidence for the marginal status of the $v b$ +locative construction in Old Russian temporal adverbials.

\subsection{Month}

According to rule (9a) in section 2, in Contemporary Standard Russian mesjac 'month' and the names of the months occur in the locative after the preposition $v$. This is illustrated in (17a), while (17b) shows that the bare genitive is used for partwhole relations where a shorter time-span span (e.g. den' 'day') is mentioned in addition to the month:

\footnotetext{
${ }^{10}$ For this particular example the Ipat'evskaja letopis' 1998 has vъ + locative, while Ostrowski (2003) provides a bare locative. I have not had the opportunity to check the original manuscript.
} 
(20) a. Èto slučilos' v dekabre Loc $_{1937}$ g., kogda Berija byl uže v Moskve. (Mikojan 1971-1974)

'This happened in December 1937 when Beria was already in Moscow.'

b. V pervyj den' fevralja $a_{\text {GeN }}$ byl u mèra Tel'-Aviva. (Bovin 1999)

'On the first day of February I visited the mayor of Tel-Aviv.'

With the modern Russian constructions in (20) in mind, let us consider the situation in Old Russian as represented by the Hypatian Chronicle. In constructions where the month occurs without mention of the day the relevant event took place, the only construction attested in my database is the bare genitive:

(21) Togo že lěta prestavisja mitropolitъ v Kievě Nikiforъ mesjacagen apriljagen.

'The same year the metropolitan of Kiev, Nikifor, died in April.' (p. 286)

When both month and day are mentioned, the month always occurs in the genitive. For the day, we have either the $v z+$ accusative as in (22) or a bare numeral without a preposition as in (23):

(22) V to že lěto byst' znamen'e u luně měsjacagen fevraljagen Vъ 5 den'Gen.

'That year there was a sign in the moon on the fifth day of February.' (p. 251)

(23) Prestavisja Svjatoslavъ synъ Volodimerъ mesjacagen martagen 16 dbnbnom. (p. 277)

'Svjatoslav, son of the Vladimirs, died on the $16^{\text {th }}$ day of March.'

The data summarized in Table 5 and Figure 2 show that examples like (22) where the day is represented as $v z+$ accusative, is by far the most frequent construction. However, more important than the differences between the relevant constructions is what unites them, namely the fact that the month always occurs in the genitive.

\begin{tabular}{lrr} 
& \# examples & \% examples \\
\hline Bare genitive proper (no day mentioned) & 20 & 10 \\
Bare genitive with $v \checkmark+$ day in the accusative & 164 & 84 \\
Bare genitive with day (no preposition) & 12 & 6 \\
Total: & 196 & 100
\end{tabular}

Table 5: Distribution of constructions for month in the Hypatian Chronicle 


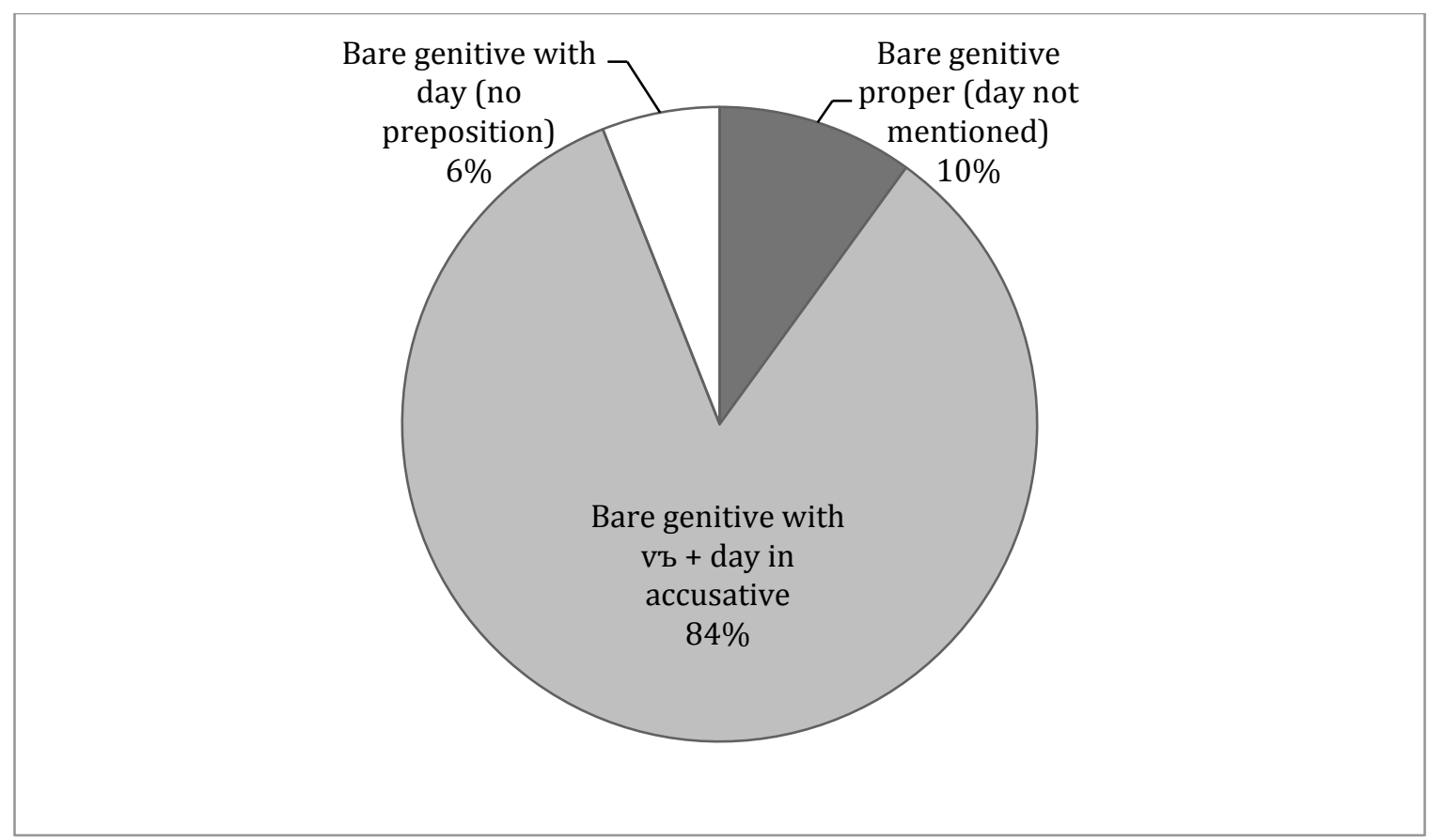

Figure 2: Distribution of constructions for month in the Hypatian Chronicle

\subsection{Summary: a rule system for Old Russian}

By way of summary, consider the following rule system for Old Russian, where commas indicate variation between constructions and parentheses indicate that the relevant construction is marginal:

a. Year as new information $\rightarrow v z+$ accusative

b. Year as given information $\rightarrow v ъ+$ accusative, bare genitive, bare locative, (vz + locative)

c. Month $\rightarrow$ bare genitive

Although these rules only concern 'year' and 'month', they facilitate answers to three questions: Are the rules for 'year' and 'month' different in Old Russian? Are the Old Russian and modern Russian systems different? And are there examples of magnitude-sensitive (Euclidean) semantics in Old Russian? Let us consider each question in turn. First, as for the differences between 'year' and 'month', rules (24a) and (24b) show that 'year' combines with several constructions, while 'month' always takes the bare genitive, as shown in (24c). Second, the fact that in Old Russian 'year' and 'month' fall under different rules, while in Contemporary Standard Russian we need only one rule (rule (9a)) indicates that the systems in Old Russian and Contemporary Standard Russian are different. With regard to the third question about Talmy's generalization, we have no compelling evidence for magnitude-sensitive semantics in Old Russian, since in (24) there is no rule that corresponds to the magnitude-sensitive rule (9a) in Contemporary Standard Russian. Admittedly, 'year' and 'month' behave differently, but this is not magnitude sensitivity in the relevant sense, since in Old Russian it is not the case that all time 
spans longer than a week behave in a special way with regard to case government. In fact, Old Russian is not more exotic than English, where weekdays take the preposition on (on Thursday), while day parts take in (in the morning). The only possible argument for magnitude sensitive semantics in Old Russian would come from the bare genitive construction, which, as we have seen, is attested for both 'year' and 'month'. If this construction were not attested for shorter time spans, we would have an argument for magnitude sensitivity in Old Russian. However, this is not the case. The adverbs segodnja 'today' and včera 'yesterday', which are "frozen" genitive forms, and set expressions such as tret'ego dnja 'the day before yesterday' show that the bare genitive construction was not originally restricted to time spans longer than a week (cf. Borkovskij and Kuznecov 1963, 428-429), and the following examples with dbnь 'day' and nočb 'night' indicate that the bare genitive construction was not restricted to long time spans in the Hypatian Chronicle:

(25) Togo že dni $i_{\text {GEN }}$ polci ustrětošasja.

'The same day the Polovtsians were met.' (p. 691)

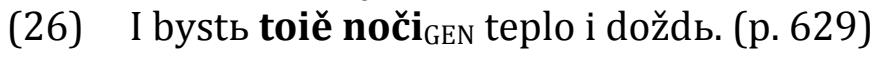

'An that night it was warm and it rained.'

Given that Contemporary Standard Russian, but not Old Russian displays magnitude-sensitive semantics, we must ask how Contemporary Standard Russian developed this typologically unusual property. This is the topic of the following section.

\section{Sketch of Further Historical Development}

In order to shed light on the development from magnitude-neutral to magnitudesensitive temporal adverbials, we must locate the change in time and explore the factors that may have led to the development. In the following, we will see that the relevant change seems to have started in the $16^{\text {th }}$ century, and that it is related to changes in case syntax (the disappearance of the temporal bare genitive and the bare locative), as well as changes in the aspectual system (the emergence of perfective delimitative verbs) and a change in the meaning of nedelja. My analysis lends support to Harris' (2008) proposal that typologically unusual constructions are the result of the interaction of several usual historical processes.

\subsection{Location in time: late Middle Russian}

Examples with $v$ z followed by 'year' in the (second) locative case are attested from the 1500s, when godz has started to replace lèto as the word for 'year'. Although in the following sentence from Domostroj vъ is not separated from the following noun phrase, it is clear that we are dealing with a prepositional phrase: 


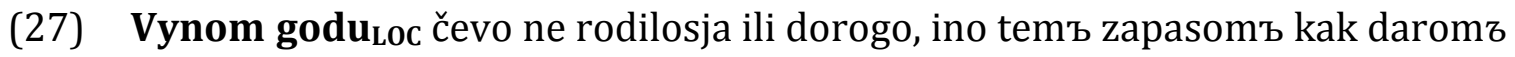
proživet, a nužnogo i bolnovo, i nedostatočnovo ssudit i podmožetъ, komu kakъ prigože. (Domostroj ${ }^{11}$ )

'If in some year something does not grow or is expensive, then one must live on one's supplies and lend to the underprivileged or ill or poor, and help them as much as one can.'

Examples of this kind seem to become more frequent in the 1600s. Here are two examples from archpriest Avvakum's pen: ${ }^{12}$

(28) A v našej Rossii bystb znamenie: solnce zatmilosь $\mathbf{v} 162$ goduLoc. (Avvakum, p. 67)

'But in our Russia there was a sign: there was an eclipse of the sun in the year $162 . '$

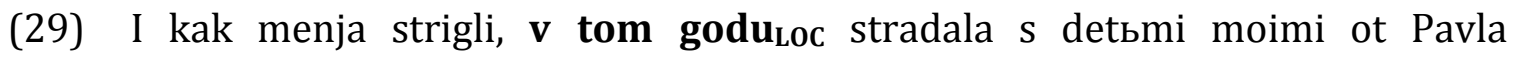
mitropolita na patriarchove dvore very radi i pravosti zakona. (Avvakum, p. 154)

'When I was tonsured, in that year she and my children suffered because of Metroplitan Pavel for their faith and the rightness of the law.'

With regard to 'month', I have found only one example from the 1500s:

(30) Kakъ sie gosudarıskoe pisanıe dojdetъ, vědomo da estь Jaganu, korolju Svějskomu i Gotckomu i Vendijskomu, čto prež sego dana tebě zapovedı $\mathbf{v}$ genvarěLoc mesjacěLoc. (Ivan Groznyj: Poslanie švedskomu korolju Juchanu III 1572 goda $^{13}$ )

'When you receive this state letter, you, John, king of Swedes, Goths and Vendians, will already know about a second instruction, which we made earlier, in the month of January.'

From the $1700 \mathrm{~s}$, however, $v z+$ locative is widely attested in the writings of e.g. Lomonosov, Sumarokov and Karamzin:

(31) Estbliby naša masljanica položena byla vъ maěLoc měsjacěLoc, to velikij postъ bylъ by vъ polnoj vesně i vъ načalě lěta. (Letter from $M$. V. Lomonosov to I. I. Šuvalov, dated November 1, 1761, available at Biblioteka Moškova ${ }^{14}$ )

'If our Shrovetide would be placed in the month of May, then Lent would be late in spring or in the beginning of the summer.'

(32) Ja v ischode leta, $\mathbf{v}$ mesjace Loc $_{\text {avguste }}$ Loc ustremljajusja videti $\mathrm{v}$ P<eter>burge oči v. v.; no s čem ja pojavljusja, kogda Dmitrevskij v samoe to $v$ remja $a_{A c c}$ radi svoego izlišnego nasyščenija budet $v$ Moskvu? (A. P.

\footnotetext{
${ }^{11}$ http://lib.pushkinskijdom.ru/Default.aspx?tabid=5145

12 The examples from Avvakum are cited after Žitie protopopa Avvakuma im samim napisannoe $i$ drugie ego sočinenija. Mocow: ZAO “Svarog i K”, 1997.

$13 \mathrm{http}: / /$ lib.pushkinskijdom.ru/Default.aspx?tabid=9116

${ }^{14}$ http://az.lib.ru/l/lomonosow_m_w/text_0130oldorfo.shtml
} 
Sumarokov: Letter to Catherine II, dated May 20, 1773, available in Biblioteka Moškova ${ }^{15}$ )

'Late in summer, in the month of August I will go to see you in Petersburg, but what will I be able to show you when at the same time Dmitrievskij will arrive in Moscow because of his superfluous business.'

(33) $\mathbf{V}$ ijule $_{\text {Loc }}$ mesjace $_{\text {Loc }} \mathbf{v}$ samyj žarkij denbacc naslaždalisь my zdesь prochladoju, kak v samom dremučem, dikom lesu. (N. M. Karamzin: Pis'ma russkogo putešestvennika, 1790, available in Biblioteka Moškova ${ }^{16}$ )

'In July, on the hottest day, here we enjoyed the cool like in the densest and wildest forest.'

It is interesting to notice that in examples like (32) and (33) the distribution of the locative and accusative cases is in harmony with the rules for Contemporary Standard Russian outlined in (9). While mesjacz is in the locative in both examples, vremja 'time', an unbounded time span, and denb 'day', a bounded time span shorter than a week, are in the accusative.

Since the available evidence suggests that the change from the Old Russian magnitude-neutral system to the modern magnitude-sensitive system started in the 1500s and gained momentum in the following two centuries, we must ask which factors may have occasioned this change in late Middle Russian. How did $v z+$ locative become the main construction for temporal adverbials involving bounded time spans longer than a week? This question will occupy us in section 4.2.

\subsection{Relevant factors: case and aspect}

As mentioned above, I suggest that the change in temporal adverbials is related to changes in case syntax and aspect. Let us consider case first. In section 3 we saw that three major constructions in Old Russian were used in the temporal adverbials we are interested in: $v z+$ accusative, the bare locative, and the bare genitive. Whereas $v ъ+$ accusative remains the unmarked, default construction in Contemporary Standard Russian, the importance of the other two constructions has decreased; the bare locative has disappeared completely, and the bare genitive is now restricted to dates (as well as to examples with part-whole relations such as (16) and (20b)).

According to Toporov (1961, 10; see also Pavlova 1977, 197ff.), the bare locative was still a "living phenomenon" ("živoe javlenie") in Old Russian, although it was gradually replaced by the $v ъ+$ locative construction. In spatial constructions, the bare locative was used longer with toponyms than with common nouns, and names of large and well-known towns were most resilient to change (Pavlova 1977, 200f.). The bare locative was in use longer in temporal expressions, but finally died out in the 16th and 17th centuries (Toporov 1961, 22), i.e. around the time when $v z$ + locative becomes the major construction for 'year' and 'month'. It is possible that

15 http://az.lib.ru/s/sumarokow_a_p/text_0260.shtml

16 http://az.lib.ru/k/karamzin_n_m/text_0320.shtml 
the general tendency to replace the bare locative by the $v z+$ locative construction helped pave the way for the $v z$ + locative construction in temporal expressions too.

The bare locative was not the only construction to hit on hard times. As demonstrated by Grannes (1986, 60; see also Bulachovskij 1954, 333), the bare genitive in temporal expressions (also known as genitivus temporis) made a "swift decline" in the 18th century. Both the replacement of the bare locative and the decline of the bare genitive involve change from a synthetic to an analytic language type, since bare cases yielded to prepositional constructions (cf. Grannes 1986, 58ff.).

The decline of the two constructions with bare cases left the $v z+$ locative construction with only one competitor, namely $v z+$ accusative. As shown in section $3, v z+$ accusative was the unmarked, default construction already in Old Russian while $v z$ + locative was marginal, so this was David's battle with Goliath. Nevertheless, David (i.e. the marginal $v z+$ locative construction) won the battle. How could this happen? I suggest that at least a partial explanation is that David received help from changes in the aspectual system. ${ }^{17}$ In order to understand the relationship between temporal adverbials and aspect, we first need to consider the meaning of the $v z+$ locative construction in spatial expressions such as $v$ komnate Loc 'in a room' where the preposition $v$ and the locative case jointly indicate the stative location of an object within a bounded space (which for simplicity will be referred to as a "container"). If we assume that temporal expressions are related to spatial expressions through the TIME IS SPACE metaphor (cf. e.g. Haspelmath 1997), temporal adverbials with the $v z+$ locative construction entail the conceptualization of a time span as a metaphorical container where an event is located. The beginning and end of the time span correspond to the edges of the container, while the time between the beginning and end corresponds to the space inside the container. In other words, in expressions such as vъ maě měsjacě 'in the month of May' in (31) the month of May can be conceptualized as a metaphorical container, within which an event is located - in this case the celebration of Shrovetide. Were there any changes in the late Middle Russian period that involved the conceptualization of time in terms of stative location inside a container? I suggest that the emergence of atelic perfective verbs is a case in point.

Perfective verbs are typically telic (achievements or accomplishments) in the sense that they involve an inherent limit (telos), after which they cannot continue (cf. Dickey 2008, 331 for discussion). For instance, napisat' pis'mo 'write a letter to completion' entails that the process of writing goes on until the whole letter is completed and the writing of the letter cannot continue. However, Contemporary Standard Russian also has a large class of atelic perfectives. Most important among them are verbs of the so-called delimitative aktionsart such as popisat' 'write for a while'. As pointed out by Dickey $(2008,331)$, such perfective verbs are atelic in the sense that they only describe the involvement in an activity for an indefinite period of time; there is no entailment of a process reaching a telos/inherent endpoint.

I propose that delimitative perfectives such as popisat' define metaphorical containers that are comparable to those defined by the $v+$ locative construction in 
temporal adverbials. The addition of the prefix po- to imperfective activity verbs such as pisat' 'write' imposes two temporal boundaries on the activity - a starting point and an end point. Insofar as the activity takes place within these boundaries, a delimitative perfective can be conceptualized as a metaphorical container within which the activity is located. Notice that atelicity squares with the idea of stative location. While telic verbs like napisat' can be conceptualized as following a metaphorical path towards a goal, atelic verbs such as popisat' resemble stative location insofar as there is no (metaphorical or literal) movement along a path towards a goal.

My proposal that the $v z+$ locative construction and delimitative perfectives involve the location of events in metaphorical containers, and the idea that delimitative verbs are related to the spread of the $v z+$ locative construction in late Middle Russian imply that delimitative perfectives emerged at the same time as $v z+$ locative became the major construction for 'year' and 'month'. This prediction is borne out by the facts. Dickey (2008), who relies on Sigalov 1975, has shown that although there was a small number of delimitative verbs already in Common Slavic, "delimitative po- was only marginally productive before the seventeenth century, when it began a period of increasing productivity that continues into the present" (Dickey 2008, 331). In other words, delimitative po- became productive in late Middle Russian - approximately at the time when the shift from magnitude-neutral to magnitude-sensitive temporal adverbials took place. The concurrence in time and the fact that both delimitative perfectives and the $v z+$ locative construction involve conceptualization of time in terms of location in a metaphorical container, strongly suggest that we are dealing with two related phenomena. However, I hasten to add that there is no indication that one phenomenon caused the other. According to a more likely scenario, the two phenomena are symptoms of the same cause, but the evidence adduced in the present study does not enable us to establish exactly what this cause might have been. ${ }^{18}$

We have now considered four linguistic changes in late Middle Russian:
a. Decline of the bare genitive
b. Loss of the bare locative and its replacement with $v z+$ locative
c. Ousting of $v ъ+$ accusative by $v z+$ locative for 'year' and 'month'

\footnotetext{
${ }^{18}$ An apparent problem for my proposal that there is a connection between the use of $v+$ locative and delimitative perfectives is the fact that in Czech and Polish $v+$ locative has become the unmarked, default construction in temporal adverbials (Makarova and Nesset to appear), although delimitative perfectives are not characteristic of West Slavic (Dickey 2011, 180). However, since the changes under scrutiny took place long after East and West Slavic had parted ways, the spread of the $v+$ locative construction in the East and West are probably independent developments. I speculate that the dominance of $v+$ locative in temporal adverbials in West Slavic is connected to the marginalization of $v+$ accuative in spatial constructions. Since in Czech the "use of $v+$ accusative [...] to indicate physical movement in space is very limited, generally encountered only in fixed expressions" (Janda and Clancy 2006,124), there is no spatial model for the use of $v+$ accusative in temporal adverbials, which may have paved the way for the temporal use of the $v+$ locative construction. However, a detailed discussion of temporal adverbials in West Slavic is beyond the scope of the present study, and the question about the development of $v+$ locative in West Slavic temporal adverbials must be left open for future research.
} 


\section{d. Increase in productivity of delimitative po-}

We have seen that (34a) and (34b) are related. The replacement of the bare locative and the decline of the bare genitive are both examples of changes from a synthetic to an analytic language type, insofar as bare cases are replaced by constructions involving prepositions. We have furthermore seen that there is a conceptual link between (34c) and (34d), since both changes involve stative location of events in metaphorical, temporal containers. However, we do not have evidence suggesting any connection between (34a-b) on the one hand and (34c-d) on the other; the changes from synthetic to analytical constructions and the emergence of stative location in temporal containers appear to be unrelated, although they occur at approximately the same time in Middle Russian. In the following section, we turn to yet another independent factor relevant for the development of magnitude-sensitive grammatical structures for temporal adverbials in Russian.

\subsection{The lexicon: an independent change involving nedelja}

To the extent that the factors mentioned above suffice to motivate the emergence of temporal adverbials with $v ъ$ + locative, we must ask why this construction did not spread to time spans shorter than a week. Why didn't this construction oust the $v 6+$ accusative construction completely? In the following, I suggest that the changes in the lexical meaning of nedelja play an important role.

It seems that long, bounded time spans are the best candidates for metaphorical containers. Containers have boundaries (edges), so unbounded time spans such as vremja 'time' would not be a good match. Furthermore, in order for something to qualify as a container, it must have some extension. Therefore, longer time spans seem to be better candidates for metaphorical containers, while shorter time spans are more easily conceptualized as points, i.e. as entities with minimal extension.

If we accept the idea that long, bounded time spans are the best candidates for metaphorical containers, such time spans would be the first to adopt the $v z+$ locative construction. As we have seen, this prediction is borne out by the facts. However, why didn't the construction spread to time spans such as weeks and days? Even though longer time spans may be more naturally conceptualized as metaphorical containers, it is nevertheless perfectly possible to conceive of weeks and days as containers. Since the length of a time span is a scalar property there is no natural cutoff point between those time spans that can be conceptualized as containers and those that cannot.

I suggest that another independent language change provides motivation for 'week' as the cutoff point. In Contemporary Standard Russian, the word for 'week', nedelja, is used with $n a$ 'on' + locative in temporal adverbials:

(35) Èto slučilos' na prošloj nedele $e_{L o c}$, soveršenno neožidanno. (Goljachovskij 1984-2001)

'This happened last week, completely unexpectedly.' 
Since nedelja combines with a different preposition than other bounded time spans (second, minute, day parts, day, month, year etc.), nedelja forms a natural pivot in the system, whereby time spans shorter than a week take $v z+$ accusative, whereas $v \checkmark+$ locative is used for time spans longer than a week. The fact that nedelja occurs in a different construction presents language-internal motivation for 'week' as the cutoff point between those time spans that are conceptualized as metaphorical containers and those that are not.

Interestingly, the original primary meaning of nedelja was 'Sunday', i.e. the 'day for rest' (cf. ne 'not' and delo 'activity'), and the meanings 'Sunday' and 'week' coexisted in Old Russian until voskresenie/voskresenbe 'resurrection' replaced nedelja as the word for 'Sunday' in the 15th century (Flier 1984, 146, see also Flier 1985). ${ }^{19}$ In Old Russian, $n a$ was frequently used in temporal adverbials denoting holidays (Lomtev 1956, 333), so one may speculate that the reason why nedelja in Contemporary Standard Russian combines with $n a$ is the fact that it originally meant 'Sunday'. According to Haspelmath $(1997,115)$ the use of special adpositions in temporal adverbials denoting holidays or leisure time is common across languages. While a detailed analysis of how the different behavior of nedelja developed historically is beyond the scope of the present study, it seems clear that nedelja provides motivation for the cutoff point between the time spans that are conceptualized as containers and those that are not. In other words, the lexical shift in nedelja had an impact on the development of magnitude-sensitive temporal adverbials - in addition to the factors mentioned above, namely the changes promoting analytical constructions with prepositions and the emergence of atelic perfective verbs. ${ }^{20}$

In her study of the Caucasian languages Georgian and Udi, Harris $(2008,76)$ suggests that "typologically unusual constructions [...] are due to the unusual cooccurrence of quite usual processes". In other words, in Harris' view, typologically unusual properties result from historical "accidents" whereby two or more independent historical processes interact so as to produce a typologically uncommon result. Although Harris' case studies are not entirely parallel to the phenomena discussed in the present study, the analysis presented above lends support to Harris' main idea. In the previous section, we considered two independent changes, namely the development of analytical constructions and the emergence of stative location in temporal containers. The change in the meaning of nedelja, which we have explored in the present section, appears to be yet another

\footnotetext{
${ }^{19}$ The semantic shift from 'Sunday' to 'week' is a pedestrian example of a metonymic shift from part to whole, since Sunday is part of the week.

${ }^{20}$ In addition to the change in the meaning of nedelja, another lexical shift that might have had a bearing on the emergence of magnitude-sensitive temporal adverbials concerns 'year'. While the Old Russian adverbials explored in section 3 involve lěto, the Middle Russian examples with $v ъ$ + locative in section 4.1 have godz. A possible hypothesis would be that godz 'time' occurred frequently in the $v z+$ locative construction in Old Russian, and that the preference for $v 6$ + locative continued after godz changed its meaning. However, I am not aware of any evidence in support of this hypothesis, since major dictionaries offer no examples with $v ъ$ + locative for Old Russian godz 'time'. I conclude that the lexical shift in godz was not of major importance for the development of magnitude-sensitive temporal adverbials in Russian.
} 
independent process. Despite the fact that all the relevant changes are natural historical processes, their interaction in the same historical period has created a typologically unusual property of Russian, namely magnitude-sensitive grammatical structures for temporal adverbials.

\section{Conclusion and implications: historical linguistics and language typology}

In this study of temporal adverbials in Russian I have explored the relationship between historical linguistics and language typology. After having clarified Talmy's generalization that closed-class elements tend to have magnitude-neutral ("topological") rather than magnitude-sensitive ("Euclidean") meanings in section 1, I demonstrated in section 2 that Contemporary Standard Russian is typologically unusual since it has magnitude-sensitive ("Euclidean") temporal adverbials. In section 3 we saw that there is no compelling evidence for magnitude-sensitivity in the Old Russian temporal adverbials. In section 4, we saw that the change in the temporal adverbials took place in late Middle Russian, and I proposed that the change is related to three independent groups of changes: (a) the decline of bare case constructions and the promotion of analytical constructions with prepositions, (b) the emergence of atelic perfectives that involve conceptualization of time in terms of stative location in metaphorical containers, and (c) the change in the lexical meaning of nedelja. Since (a), (b) and (c) appear to be completely independent processes, the present study lends support to Harris' (2008) idea that typologically unusual constructions emerge through the interaction of independent historical processes.

The present study opens up a number of alleys for future research. First of all, I have focused on only 'year' and month', so it would be interesting to find out when and how the $v+$ locative construction emerged for other time spans such as 'decade', 'century' and 'millennium'. Second, the question arises whether there are further examples of magnitude-sensitive grammatical structures in other temporal adverbials in Russian. Third, an interesting area for further study would be the historical development of temporal adverbials in other Slavic languages. These and other unresolved questions notwithstanding, the present study has shown that the history of Russian sheds light on the relationship between language typology and historical linguistics.

\section{References}

Avvakum Petrovič (1997): Žitie protopopa Avvakuma im samim napisannoe i drugie ego sočinenija. Mocow: ZAO "Svarog i K”.

Borkovskij, Viktor I. and Petr S. Kuznecov (1963): Istoričeskaja grammatika russkogo jazyka. Moscow: Izdatel'stvo Akademii Nauk SSSR.

Bulachovskij, L. A. (1954): Russkij literaturnyj jazyk pervoj poloviny XIX veka: Fonetika, morfologija, udarenie, sintaksis. Moscow: Gosudarstvennoe učebnopedagogičeskoe izdatel'stvo ministerstva prosveščenija RSFSR.

Chomsky, Noam and Morris Halle (1968): The Sound Pattern of English. New York: Harper \& Row. 
Dickey, Stephen M. (2008): A prototype account of the development of delimitative po- in Russian. In: Divjak, Dagmar and Agata Kochanska (eds.): Cognitive Paths into the Slavic Domain. Berlin: Mouton de Gruyter, 326-371.

Dickey, Stephen M. (2011): The varying role of $p o$ - in the grammaticalization of Slavic aspectual systems: sequences of events, delimitatives, and German language contact, Journal of Slavic Linguistics 19,2: 175-230.

Flier, Michael S. (1984): Sunday in medieval Russian culture: nedelja versus voskresenie. In: Birnbaum, Henrik and Michael S. Flier (eds): Medieval Russian culture. Berkeley, Los Angeles and London: University of California Press, 105149.

Flier, Michael S. (1985): The non-Christian provenience of Slavic nedělja, International Journal of Slavic Linguistics and Poetics 31-32: 151-165.

Grannes, Alf (1986): Genitivus temporis in early $18^{\text {th }}$ century Russian, Russian Linguistics 10: 53-60.

Harris, Alice C. (2008): On the Explanation of Typologically Unusual Structures. Linguistic Universals and Language Change. Ed. Jeff Good. Oxford: Oxford University Press: 54-76.

Haspelmath, Martin (1997): From space to time: temporal adverbials in the world's languages. Munich: LINCOM Europa.

Ipat'evskaja letopis' (1998): volume 2 of Polnoe sobranie russkich letopisej. Moscow: Jazyki russkoj kul'tury.

Janda, Laura A. and Steven J. Clancy (2006): The Case Book for Czech, Bloomington IN: Slavica Publishers.

King, Bruce M. and Edward W. Minium (2008): Statistical reasoning in the behavioral sciences. Hoboken, NJ: John Wiley \& Sons.

Lomtev, Timofej P. (1956): Očerki po istoričeskomu sintaksisu russkogo jazyka. Moscow: Izdatel'stvo moskovskogo universiteta

Makarova, Anastasia and Tore Nesset (to appear): Space-time asymmetries: Russian $v$ 'in(to)' and the North Slavic Temporal Adverbial Continuum. Accepted for publication in Russian Linguistics.

Nesset, Tore (2004): Case Assignment and Image Schemas: Russian Temporal Adverbials, Studies in Language 28.2: 285-320.

Ostrowski, Donald (ed.) (2003): The Pověst' vremennykh lět: an interlinear collation and paradosis. Cambridge, Mass: Harvard University Press.

Pavlova, Rumjana (1977): Prostranstvennye konstrukcii $v$ drevnerusskom jazyke $v$ sopostavlenii s drevnebolgarskim jazykom. Sofia: Izdatel'stvo bolgarskoj akademii nauk.

Sigalov, Pavel S. (1975): Istorija russkich ograničitel'nych glagolov [The history of Russian delimitative verbs]. Trudy po russkoj i slavjanskoj filologii: Serija lingvističeskaja [Studies in Russian and Slavic Philology] 24: 141- 181.

Talmy, Leonard (1977): Rubber-sheet cognition in language. In Woodford A. Beach, Samuel E. Fox and Shulamith Philosoph (eds.): Papers from the thirteenth regional meeting of the Chicago Linguistic Society, April 14-16, 1977: 612-628.

Talmy, Leonard (2000): Toward a Cognitive Semantics (vol. 1). Cambridge, Mass.: The MIT Press. 
Toporov, Vladimir Nikolaevič (1961): Lokativ v slavjanskich jazykach. Moscow: Izdatel'stvo akademii nauk SSSR.

Trubetzkoy, Nikolay S. (1939): Grundzüge der Phonologie. (=Traveaux du Cercle Linguistique de Prague 7)

Turner, Mark (2002): Review of Talmy, Leonard. Toward a Cognitive Semantics. Volume 1: Concept Structuring Systems. Volume 2: Typology and Process in Concept Structuring. Cambridge: MIT Press, 2000. Language 78.3: 576-578.

Vsevolodova, Majja V. (1975): Sposoby vyraženija vremennyx otnošenij. Moscow: Izdatel'stvo Moskovskogo Universiteta.

\section{Electronic resource}

Biblioteka literatury Drevnej Rusi, èlektronnye publikacii Instituta russkoj literatury (Puškinskogo Doma) RAN:

http://lib.pushkinskijdom.ru/Default.aspx?tabid=2070 